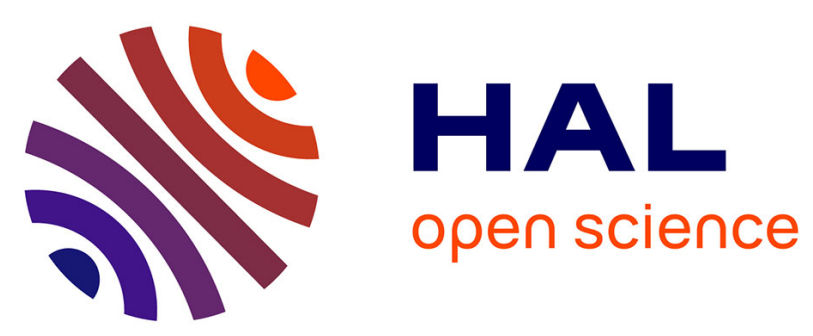

\title{
The way we wear makes the difference: residue analysis applied to Mesolithic personal ornaments from Hohlenstein-Stadel (Germany)
}

Solange Rigaud, Vanhaeren Marian, Alain Queffelec, Gwénaëlle Le Bourdon, Francesco d'Errico

\section{To cite this version:}

Solange Rigaud, Vanhaeren Marian, Alain Queffelec, Gwénaëlle Le Bourdon, Francesco d'Errico. The way we wear makes the difference: residue analysis applied to Mesolithic personal ornaments from Hohlenstein-Stadel (Germany). Archaeological and Anthropological Sciences, 2014, http://link.springer.com/article/10.1007/s12520-013-0169-9. 10.1007/s12520-013-0169-9 . hal01180664

\section{HAL Id: hal-01180664 \\ https://hal.science/hal-01180664}

Submitted on 12 Jun 2020

HAL is a multi-disciplinary open access archive for the deposit and dissemination of scientific research documents, whether they are published or not. The documents may come from teaching and research institutions in France or abroad, or from public or private research centers.
L'archive ouverte pluridisciplinaire $\mathbf{H A L}$, est destinée au dépôt et à la diffusion de documents scientifiques de niveau recherche, publiés ou non, émanant des établissements d'enseignement et de recherche français ou étrangers, des laboratoires publics ou privés. 


\title{
The way we wear makes the difference: residue analysis applied to Mesolithic personal ornaments from Hohlenstein-Stadel (Germany)
}

Solange Rigaud ${ }^{1,2}$ \& Marian Vanhaeren ${ }^{1}$ \& Alain Queffelec ${ }^{1}$ \& Gwénaëlle Le Bourdon ${ }^{3}$ \& Francesco d'Errico ${ }^{1,4}$

\author{
${ }^{1}$ University of Bordeaux, CNRS-UMR 5199 PACEA, Equipe Préhistoire, Paléoenvironnement, Patrimoine, Avenue des \\ Facultés, F-33405 Talence, France \\ ${ }^{2}$ Dipartimento di Biologia ed Evoluzione-Sezione di Biologia Evolutiva, Università di Ferrara, Via L. Borsari 46, I-44100 \\ Ferrara, Italy \\ ${ }^{3}$ Institut des Sciences Moléculaires, University of Bordeaux, CNRS-UMR 525, 351 cours de la libération, F-33405 Talence, \\ France \\ ${ }^{4}$ Institute for Archaeology, History, Cultural Studies and Religion, University of Bergen, 5020 Bergen, Norway
}

\section{Abstract}

Research conducted by Newell et al. (1990) has lead to propose that during the Mesolithic, the Upper Danube region was inhabited by a "Fish Teeth Band", characterized by the use of carp fish teeth and exogenous fossil shells as ornaments. However, technological data on these personal ornaments drastically lacked and especially for the fish teeth associated to the Mesolithic burial of Hohlenstein-Stadel that remained completely undescribed until now. The aim of this paper is to establish how the carp teeth from HohlensteinStadel were modified and worn before being deposited in the burial. High-resolution microscopic analysis identifies usewear traces and a red compound adhering to the surface of the teeth. Structural and elemental analysis of the residue combining light and scanning electron microscopy, infrared spectroscopy, and Raman analysis identify a suspension technique that uses an adhesive composed of an organic binder mixed with charcoal and minerals including hematite, dolomite, and quartz. Ethnological inquiry reveals that this system of suspension, commonly used in traditional societies, is for the first time documented, at Hohlenstein-Stadel, in an archaeological context.

Keywords Cyprinid teeth ornaments . Hohlenstein-Stadel . Pigment . Adhesive . Microscopy . Raman . EDX

\section{Introduction}

Research on Mesolithic ornaments has focused on the identification of trade networks through the sourcing of raw material (Cristiani and Borić 2012; Eriksen 2002; Komšo and Vukosavljević 2011; Rähle 1978), regional differences in bead type associations interpreted as possible reflection of cultural boundaries (Newell et al. 1990; Vanhaeren and d'Errico 2006; Rigaud et al. 2010; Rigaud 2011), and analysis of ornaments used as grave goods to assess social stratification (Albrethsen and Brinch-Petersen 1976; Larsson 2006; O'Shea and Zvelebil 1984; Rigaud et al. 2010). To provide valuable insights, these studies have to rest on precise economic and technological data to indentify behavior involved in the acquisition and transformation of the raw material for beads manufacture (White 2008; d'Errico and Vanhaeren 2002; Vanhaeren and d'Errico 2003; 2005; Bonnardin 2009; d'Errico and Rigaud 2011). With this aim in mind, the present study focuses on a region of Europe, the Danube Valley, that features a copious record of Mesolithic personal ornaments. Research conducted by Newell et al. (1990) has lead to propose that during the Mesolithic, the Upper Danube region was inhabited by a "Fish Teeth Band", characterized by the use of carp fish teeth associated to exogenous fossil shells as ornaments. The only publications describing the fish teeth ornaments from the Upper Danube area included low-resolution photographs of the fish teeth from the Mesolithic camp site of Burghöhle Dietfurt showing a lateral drilled perforation (Taute 1990, Fig. 17), and a recent photo of eleven teeth from the Mesolithic burial site of Hohlenstein-Stadel, published in the catalogue of the Ulmer Museum. In this picture, no modification such as perforations, notches or incisions, are visible on the teeth.

The publication of the grave goods associated to two Mesolithic burials from Vlasac, Serbia, in the Iron Gates region, South Danube, reveals the presence of carp teeth used as ornaments. In their study, Cristiani and Borić record the presence of red pigment staining and residues, tentatively interpreted respectively as glue and remnants of skin or tendons (Cristiani and Borić 2012). These observations corroborate the hypothesis proposed by 
Radovanovic (1996: 214) according to which carp teeth may have been attached (appliqués) to the clothes of the deceased. However, no physico-chemical analyses were conducted to verify this hypothesis.

Characterization of microwear patterns and microscopic residues on archaeological stone tools is used as a means to identify worked raw material (Hardy and Moncel 2011; Mercader et al. 2008), tool function (Hardy et al. 2008) and hafting technology (Dinnis et al. 2009; Lombard and Pargeter 2008; Rots et al. 2011; Wadley et al. 2009) of past societies. In spite of the numerous studies conducted on personal ornaments, such methods were rarely used to identify systems of suspension and evaluate the behavioral complexity behind the beadwork manufacture.

Here, we apply an array of analytical techniques to analyze the residues attached to the carp teeth associated to the Mesolithic head burials of Hohlenstein-Stadel, Upper Danube, and identify the main constituents of the adhesive compound used to attach the teeth.

\section{Archaeological context}

The Hohlenstein-Stadel cave is located on the south edge of the Lone valley close to the village of Niederstotzingen (Baden-Württemberg, Germany) (Fig. 1). The site consists of a 70-m long gallery that opens to the North in the Hohlenstein cliff within the calcareous massifs of the Swabian Jura (Fig. 1).
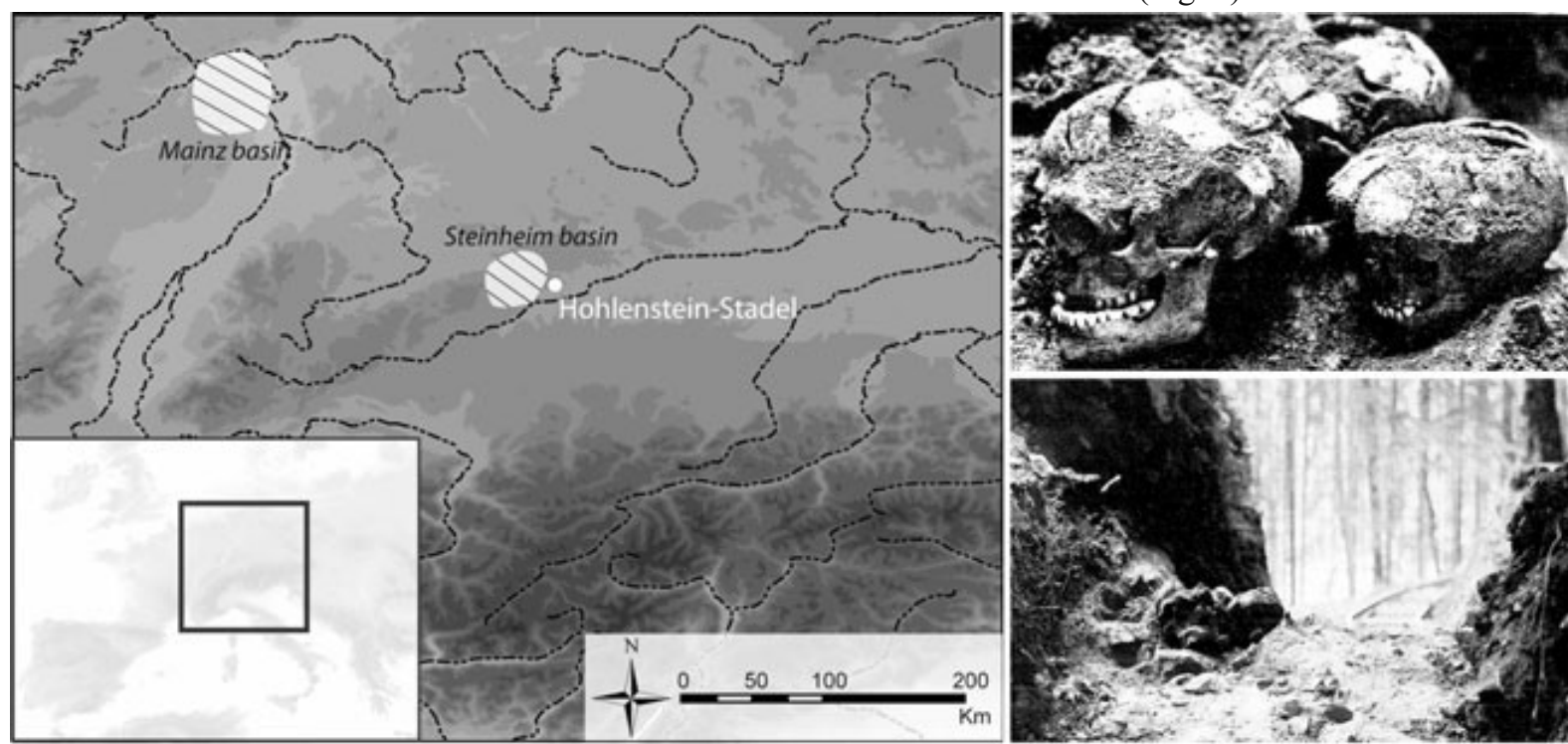

Fig. 1 left Location of Hohlenstein-Stadel archaeological site; right photographs of the skulls at the moment of their discovery (after Wetzel 1938)

The cave was excavated in 1935, and between 1937 and 1939. In 1998, new excavations, directed by Bolus, Conard, and Kandel, focused on the entrance and a small sector inside the cave (Bolus et al. 1999; Kind and Beutelspacher 2009; Wetzel 1938). A new ongoing excavation, directed by Kind (Landesamt für Denkmalpflege Baden-Württemberg im

Regierungspräsidium Stuttgart), started in 2008, has identified Middle Palaeolithic, Aurignacian, Magdalenian and Final Upper Palaeolithic levels. Remains attributed to the Mesolithic, the Neolithic, the Bronze and the Iron Age were recovered at the top of the stratigraphic sequence, considered as disturbed. In 1938, Wetzel and Völzing discovered three human skulls within a large pit at the entrance of the cave (Wetzel 1938). A conventional

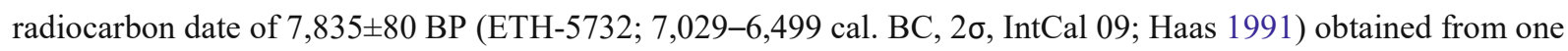
of the skulls, attributes the human remains to the Late Mesolithic.

The pit was $70 \mathrm{~cm}$ deep, cut into the Aurignacian layers, and presented an oval shape with a north-south longitudinal axis and a diameter varying between 35 and $45 \mathrm{~cm}$. From the top to the bottom (Fig. 2), the sediment filling of the pit consisted of $12 \mathrm{~cm}$ of yellow loess including small angular fragments of the cave wall, brownyellow silt with large cave wall fragments, and red-brown silt close to the bottom of the pit (Völzing 1938; Wetzel 1938). 


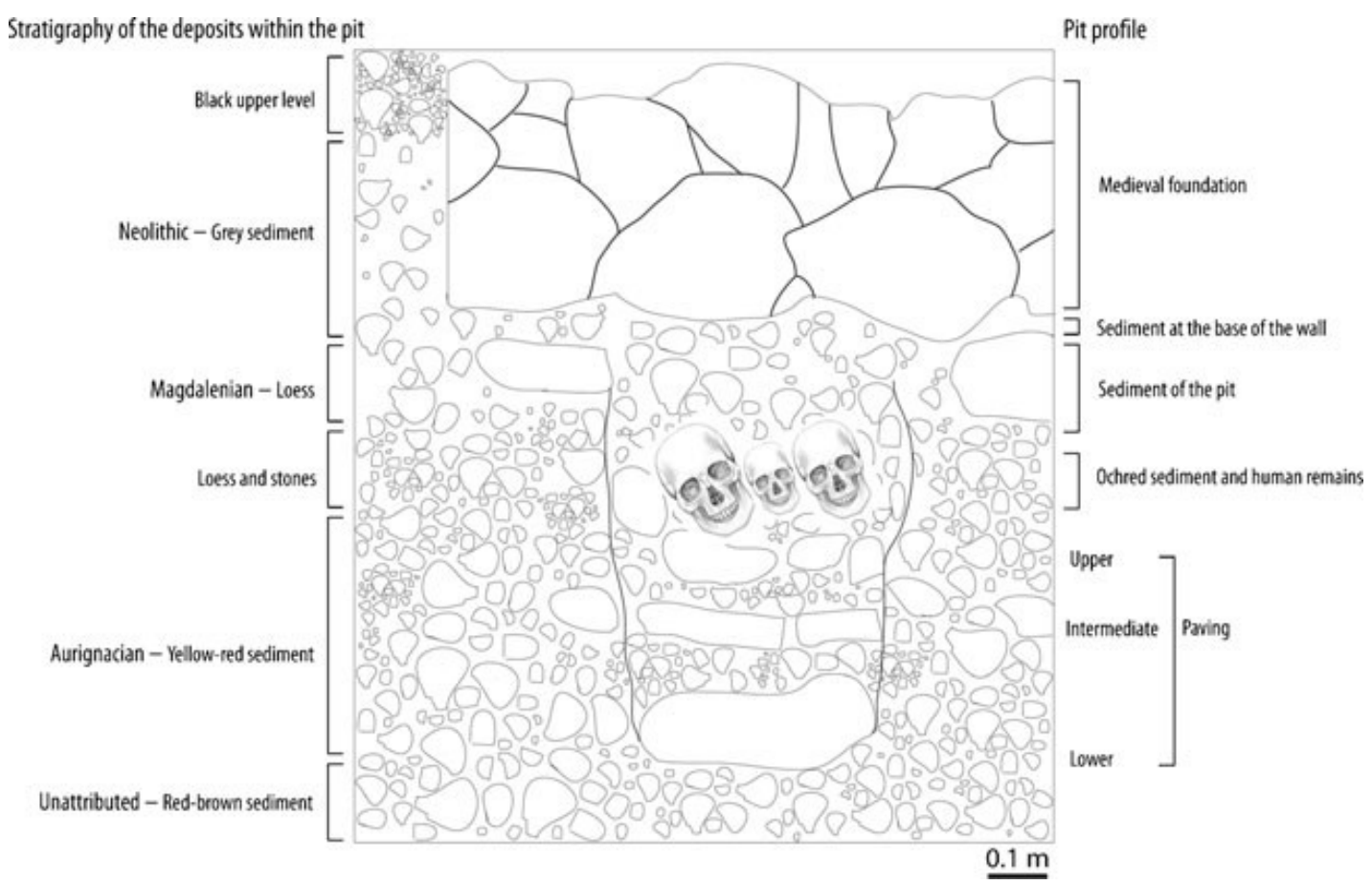

Fig. 2 Drawing and stratigraphy of the head burial pit at Hohlenstein-Stadel (modified after Wetzel 1938)

The human remains were found on top of a succession of flat stones lying on a single intensely ochred larger stone at the bottom of the pit. The human remains consisted of three human skulls each with the mandible, and two or three first cervical vertebrae for each skull (Völzing 1938; Wetzel 1938). Skull faces were oriented to the Southwest (Fig. 1). On the basis of the skull sutures, degree of eruption of the teeth, combined with their wear and some morphological criteria, two skulls were attributed to adults, a man and a woman, the third to a juvenile (Gieseler 1951; Orschiedt 1998, 1999).

Anatomical association of mandibles, cervical vertebrae and crania, and the presence of cut-marks on vertebrae indicate that the skulls were removed from the bodies and deposited in the pit a short time after the death of the three individuals (Gieseler 1951; Orschiedt 1998, 1999). Chopping traumas recorded on the parietal bones of the three skulls suggest that the individuals were injured by violent blows on the head (Gieseler 1951; Orschiedt 1998, 1999). The similarity of the Hohlenstein-Stadel skulls burial deposit with the head burials of Große Ofnet in Bavaria (Schmidt 1912) lead various authors to interpret the deposit as a cult site resulting from intergroup conflicts or as an accumulation of trophy skulls (Orschiedt 1998, 1999; Roksandic 2006; Thorpe 2003).

The only grave goods at Hohlenstein-Stadel consist of 12 fish teeth recovered in the sediment surrounding the woman's skull (Völzing 1938; Wetzel 1938). They were attributed to the Rutilus frisii meidingeri (Heckel 1851) cyprinids (Rauther 1935; Taute 1990) and interpreted as personal ornaments (Newell et al. 1990; Rähle 1978). Ten pharyngeal Cyprinid teeth of the Hohlenstein-Stadel head burial (Fig. 3) are on display at the Ulmer Museum. Their number differs from the previously published counts and indicates that two teeth were lost since the excavation conducted by Wetzel and Völzing (Wetzel 1938). 


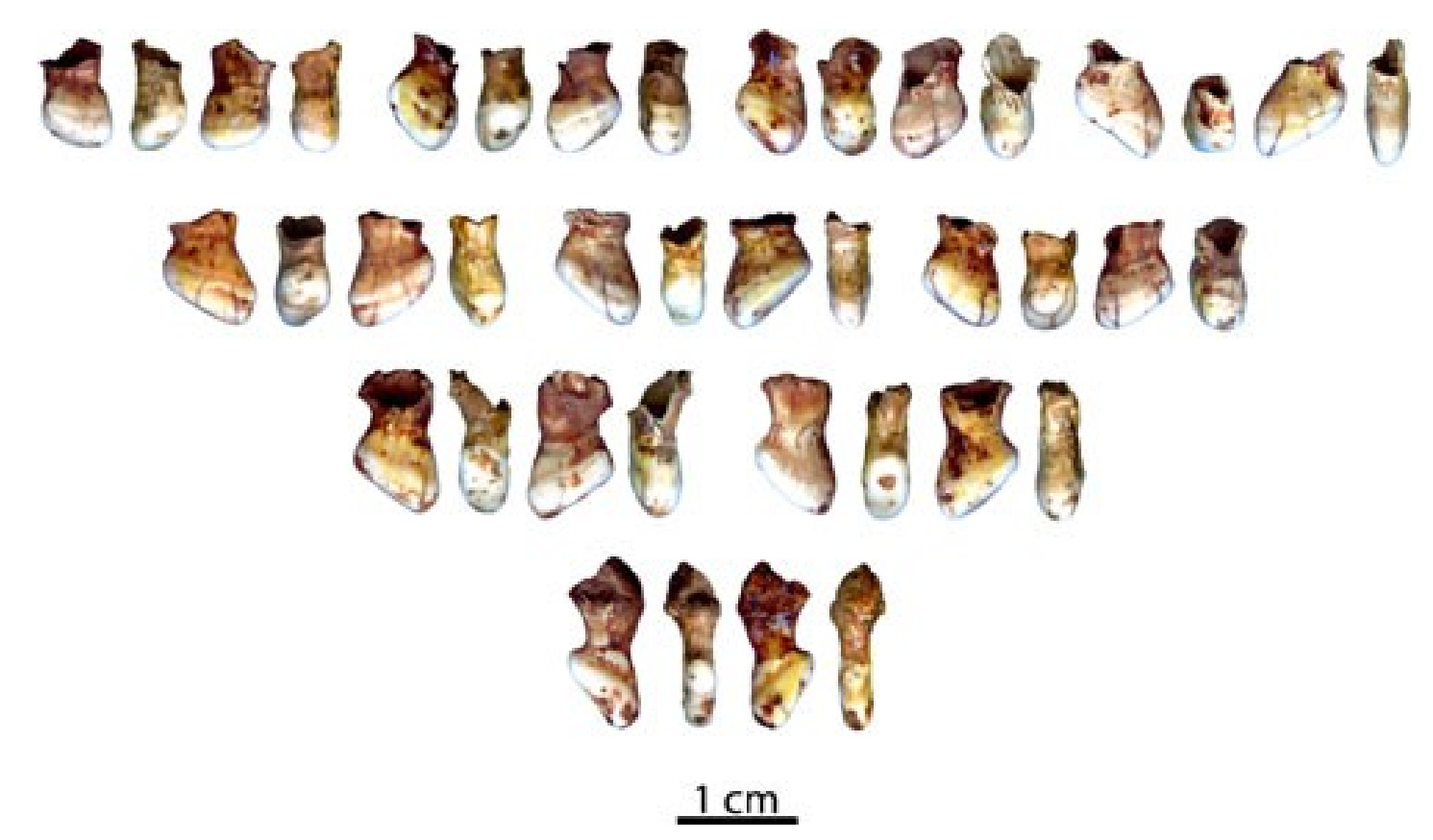

Fig. 3 Four aspects of the ten cyprinid pharyngeal teeth from the Hohlenstein-Stadel head burial. Numbers correspond to those in Table 1 and Fig. 6

A microscope Motic SMZ-168 equipped with a digital camera Jenoptik ProgRes-CT3 was used to record taphonomic and anthropogenic modifications on the surface of the teeth, including location of use-wear and presence of a pigmented compound.

The FishBase (http://www.fishbase.org/home.htm) was used to identify the current nomenclature of the fish species.

Two fragments of pigmented compound adhering to the root of two teeth, $1 \mathrm{~mm}^{2}$ in size were sampled for elemental and mineralogical analyses. Microscopic observation has revealed that the bony ankylosis of the teeth, where the pigmented compound was present, were consolidated with varnish. To avoid contamination, the sampling of the compound was conducted under the microscope in area where no varnish was present.

One sample was analyzed with a confocal Raman microspectrometer SENTERRA (Bruker Optics, Ettlingen, Germany) equipped with a $532 \mathrm{~nm}$ exciting line $(0.02-20 \mathrm{~mW})$. Spectra were obtained on mineral grains between 100 and $1,555 \mathrm{~cm}^{-1}$ with a resolution between 3 and $5 \mathrm{~cm}^{-1}$ and were automatically compared with Rruff database (Downs 2006). The other sample was submitted to Energy Dispersive X-ray analysis (EDX) performed using a Quanta 200 scanning electron microscope (SEM). Images were obtained by secondary electron (SE) and backscattered electron detectors (BSE). Micro-FTIR spectra from one compound fragment of compound were acquired using a Nicolet 6700 FTIR spectrometer (Thermo Scientific) coupled to a Nicolet Nic-Plan infrared microscope equipped with a mercury cadmium telluride (MCT) detector. Sample areas of $200 \mu \mathrm{m}$ diameter were analyzed in reflectance mode using a $15 \times$ Reflachromat Cassegrain objective (Spectra-Tech). Spectra were acquired at a spectral resolution of $4 \mathrm{~cm}^{-1}$ and by averaging 200 scans.

\section{Results}

The Hohlenstein-Stadel cyprinid teeth

\section{Identification}

The current valid name of the fish species from which the teeth were extracted is Rutilus meidingeri, (Heckel 1851). Until recently, the species existed in the entire region of the Danube, the lakes of Bavaria and Austria and 
the western part of the Caspian Sea, as well as in the Black Sea, with the exception of its southern part (Hensel 1979; Mikschi and Wolfram-Wias 1999). It disappeared from German waters about 60 years ago (Freyhof 2002).

Pharyngeal fish teeth are located behind the pharynx (Fig. 4a) (Zheltenkova 1949). They are involved in the seizing, masticating and swallowing of food. For cyprinids, the teeth are arranged in a single row of five to six teeth on each of the two pharyngeal bones (Fig. 4b, Chebotareva et al. 2009; Kottelat and Freyhof 2007). Teeth are ankylosed to the jaw and are formed of a bony neck, a crown and a main cusp (Fig. 4c).

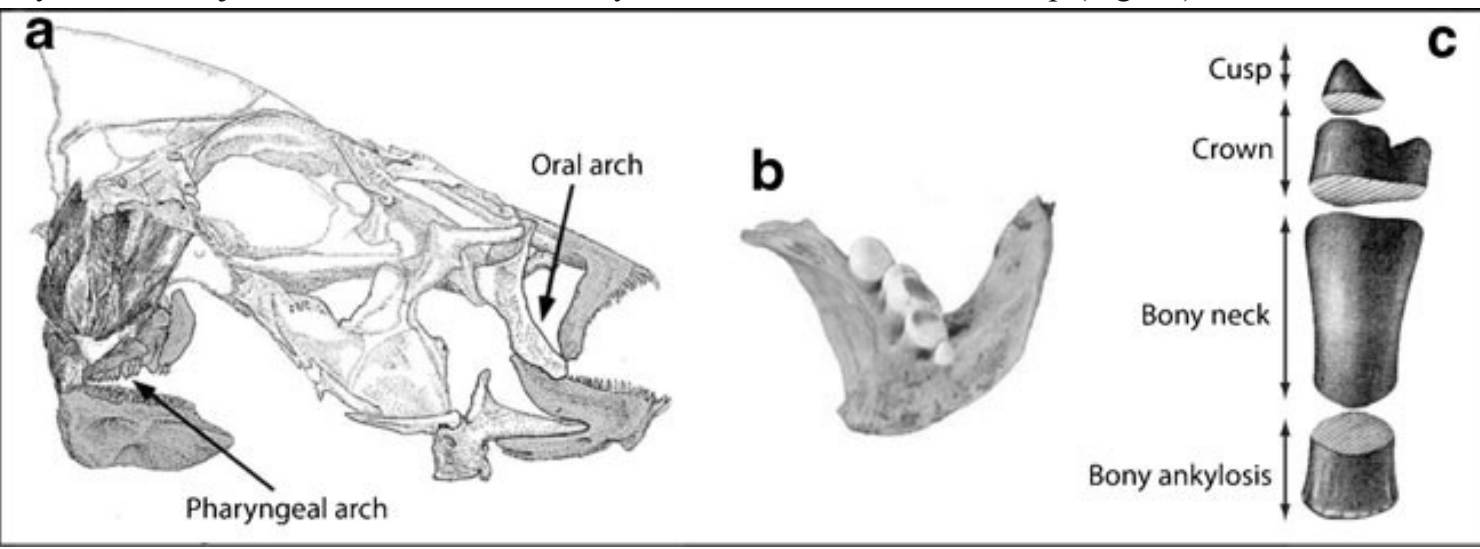

Fig. 4 Anatomy of cyprinid head bone (a), hemi pharyngeal bone (b) and teeth (c) (a, after Fraser et al. 2009, b from http://fl. biology.usgs.gov, c modified after Barel et al. 1976)

The Hohlenstein-Stadel fish teeth include six teeth from a right pharyngeal bone and three teeth from a left pharyngeal bone. One tooth cannot be lateralized because of fresh breakages (Table 1).

\begin{tabular}{|c|c|c|c|c|c|c|c|c|}
\hline No. & Length (mm) & Width (mm) & Recent breakage & Cracks & Fractured bony neck & Use-wear & Pigmented compound & Sampled \\
\hline 1 & 9.92 & 6.64 & - & - & + & + & + & - \\
\hline 2 & 10.37 & 7.81 & - & + & + & + & + & - \\
\hline 3 & 12.05 & 8.1 & - & + & + & + & + & - \\
\hline 4 & 10.19 & 9.89 & - & + & + & + & + & - \\
\hline 5 & 10.69 & 9.34 & - & + & - & + & + & - \\
\hline 6 & 10.29 & 8.81 & - & + & - & + & + & + \\
\hline 7 & 11.69 & 8.75 & - & + & + & + & + & - \\
\hline 8 & 14.36 & 9.34 & + & + & + & + & + & + \\
\hline 9 & 12.86 & 9.23 & - & - & - & + & + & - \\
\hline 10 & 16.04 & 8.73 & - & - & + & + & + & - \\
\hline
\end{tabular}

Table 1 Morphometric, taphonomic, and archaeological data recorded on the cyprinids pharyngeal teeth from the head burial of Hohlenstein-Stadel. + presence, - absence.

\section{Preservation}

The teeth are well preserved. Seven specimens present longitudinal cracks and one shows a recent breakage on the bony ankylosis and the neck. A layer of varnish partially covers their surface in places, which hampers the recording of anthropogenic modifications for those areas.

\section{Technological and use-wear analyses}

No anthropogenic modifications affecting the shape of the fish teeth, such as perforations or grooves, were observed. Irregular fractures on the bony ankylosis were registered on seven out of ten teeth (Table 1).

Use-wear was recorded on all specimens (Fig. 5c, f, o, r, v). Located around the bony ankylosis, it consists of a clear smoothing of the natural features associated with an intense shine. 


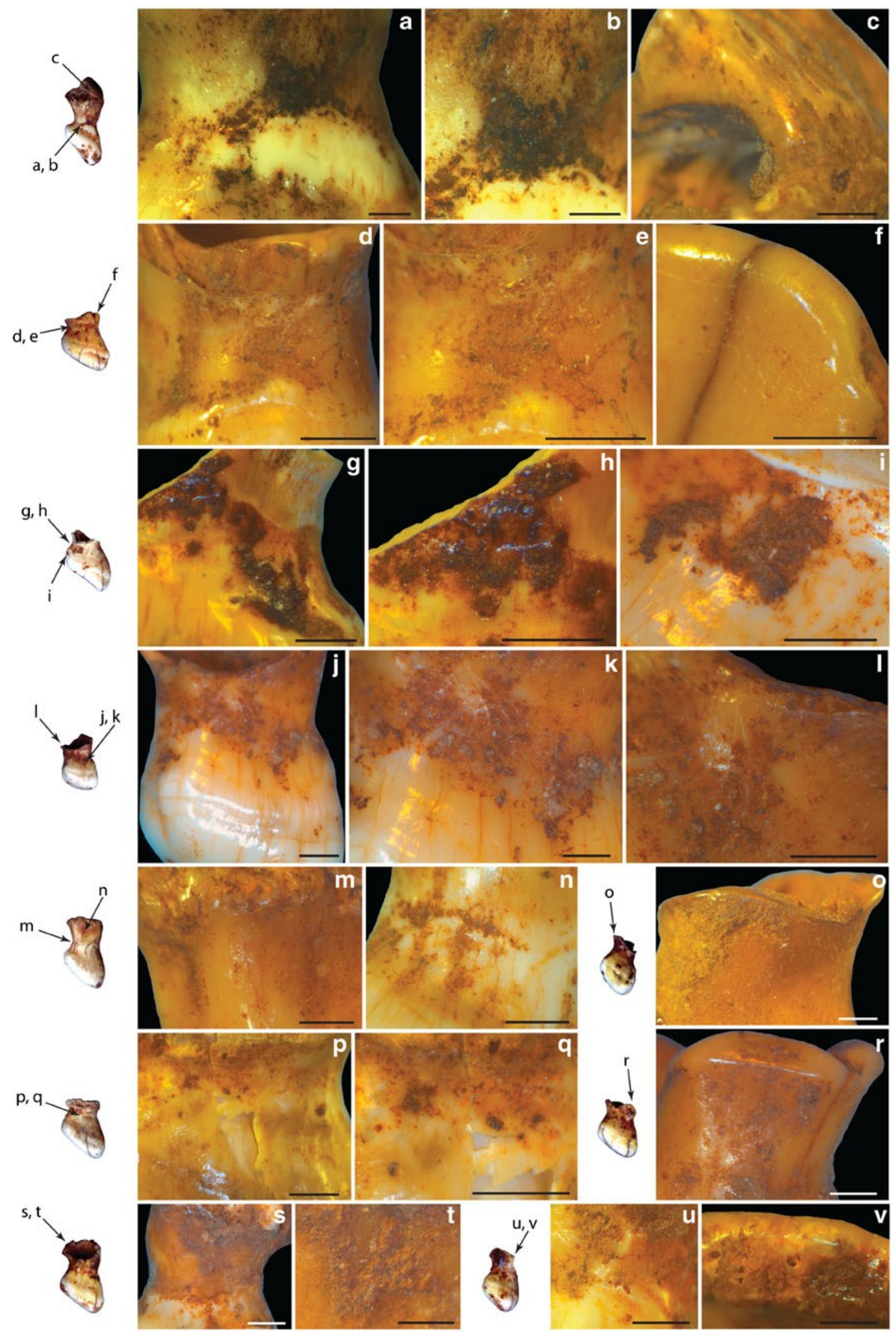

Fig. 5 Residues of a red compound (a, b, d, e, j, k, m, n, p, q, s, t, u) and traces of use-wear (c, f, 1, o, v) present on the cyprinids' pharyngeal teeth from the head burial of Hohlenstein-Stadel (scale $1 \mathrm{~mm}$ ) 


\section{Red compound}

A hard half-millimeter-thick residue of a red compound, firmly adhering to the tooth and concentrated around the neck, were found on all specimens (Fig. 6). Cyprinids teeth naturally show a natural internal hollow cavity extended from the bony neck to the cusp. Absence of sediment in the cavity is probably due to cleaning during excavation or restoration.

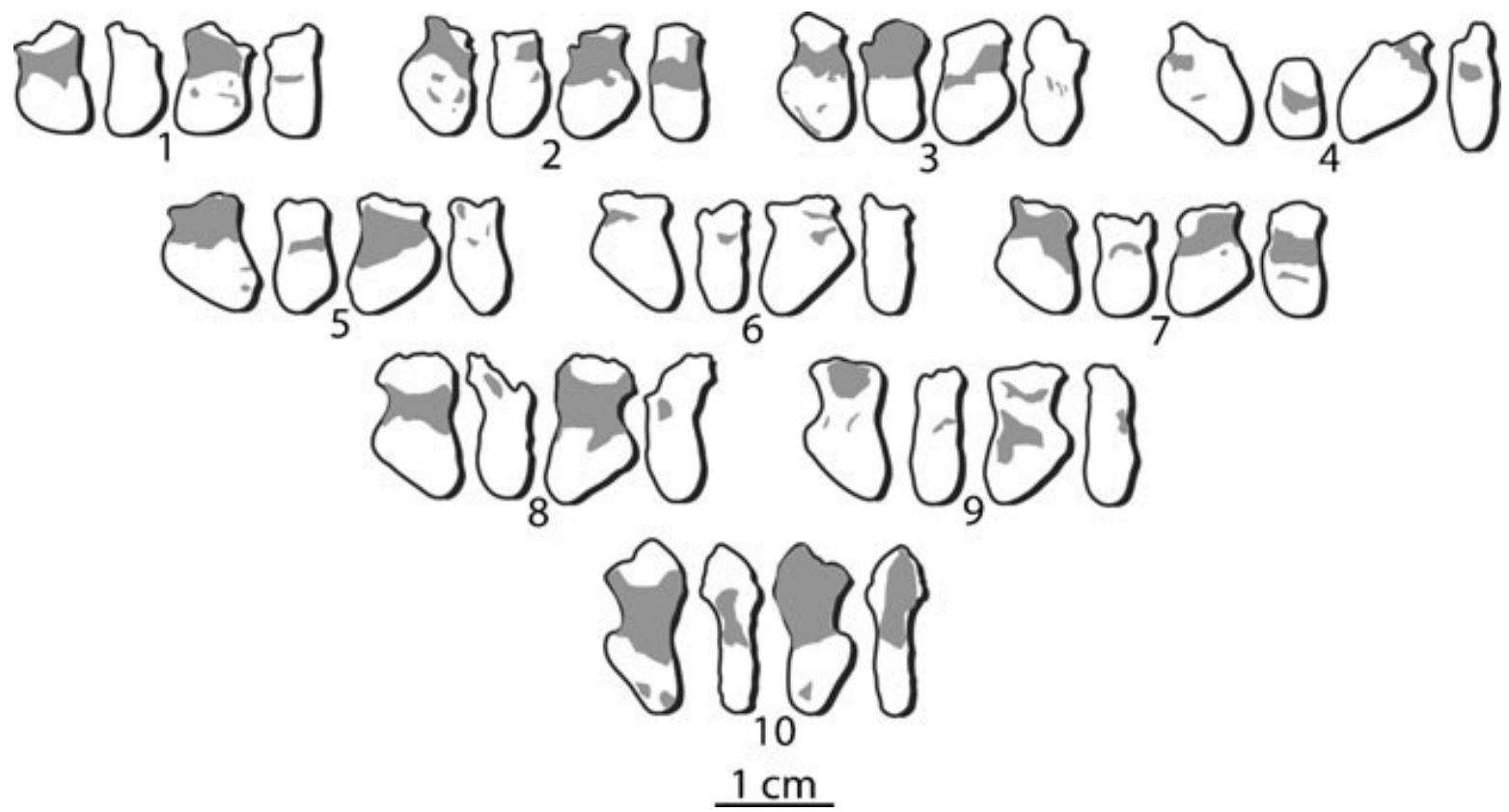

Fig. 6 Location of the red deposit (in gray) on the teeth recovered at the Mesolithic site of Hohlenstein-Stadel

Optical and SEM analyses of this residue reveal a heterogeneous texture composed of a porous matrix made of coarse angular red, white, and black grains cemented by thin red powder (Fig. 7).

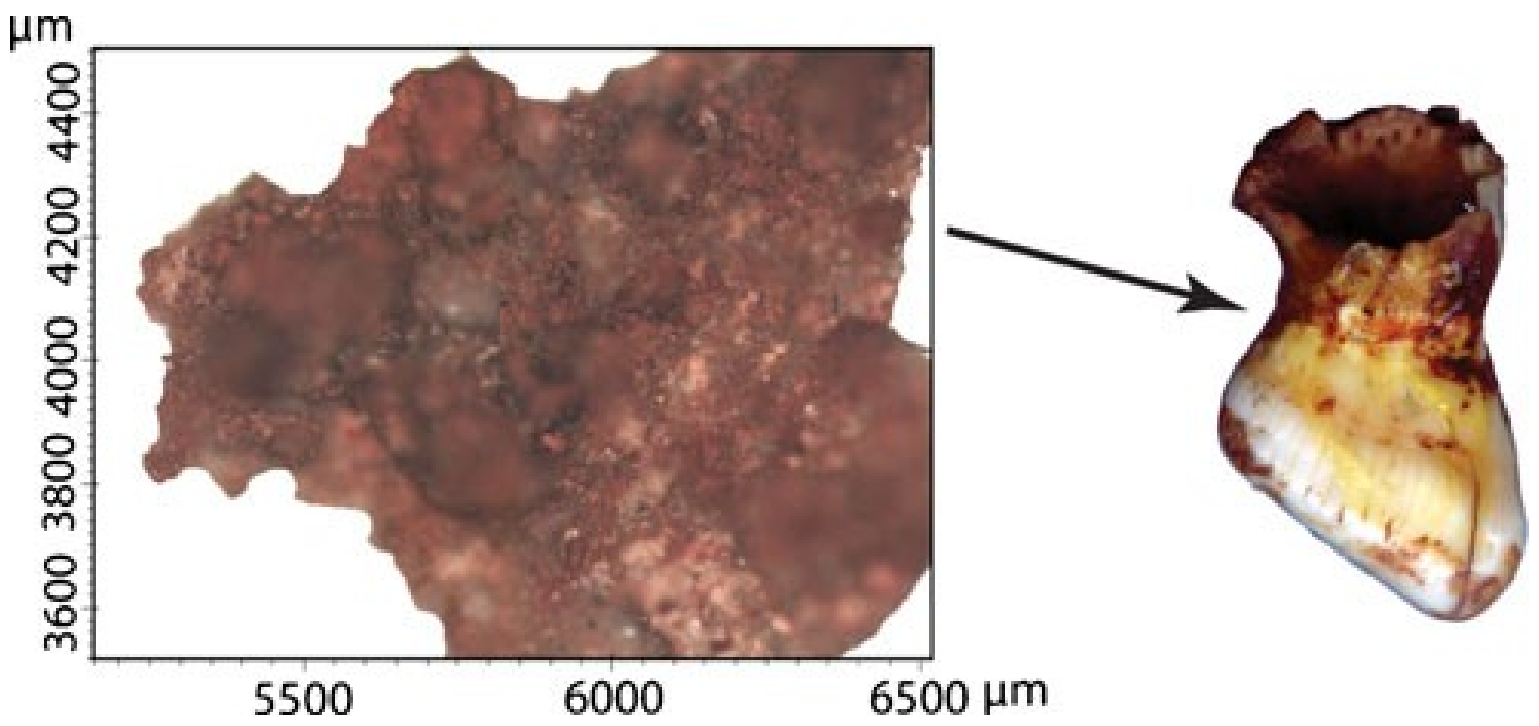

Fig. 7 Photo of the residue sampled on the teeth no. 8

Micro-Raman analysis of the sample from tooth no. 8 (Fig. 3, Table 1) identifies the red grains as hematite $\left(\mathrm{Fe}_{2} \mathrm{O}_{3}\right)$, the white grains as dolomite $\left(\mathrm{CaMg}\left(\mathrm{CO}_{3}\right)_{2}\right)$, and the black grains as charcoal (Fig. 8). Analysis of the thin powder resulted in intense fluorescence hampering the Raman signal. 

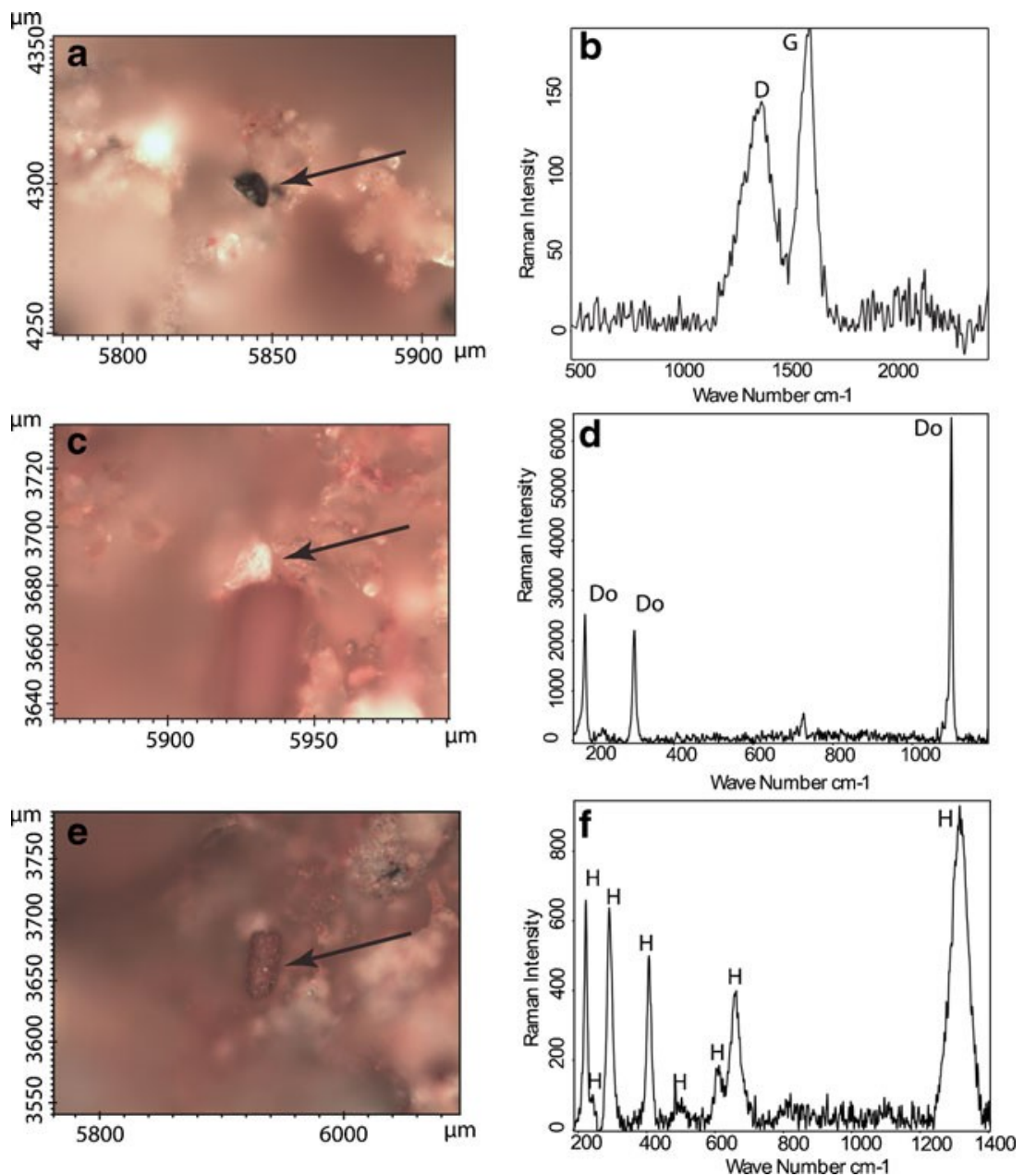

Fig. 8 Close-up views (a, c, e) and Raman spectra (b, d, f) of the grains included in the pigmented compound adhering to a Mesolithic cyprinidss tooth no. 8 from Hohlenstein-Stadel. The black grain (a) corresponds to a charcoal fragment as indicated by the $\mathrm{G}$ graphite band and the $\mathrm{D}$ amorphous carbon band (b); the white grain (c) to dolomite as shown by the Do bands (d); and the red grain (e) to hematite identified by the H bands (f) (reference spectra after Downs 2006 and Tuinstra and Koenig 1970)

SEM analysis of the pigmented residue adhering to Hohlenstein-Stadel teeth no. 6 (Fig. 3, Table 1) reveals that when observed in BSE mode, the compound is composed of middle atomic weight and small spots of high atomic weight elements. EDX elemental analysis of the matrix identifies silicon, calcium, carbon, iron, aluminum and potassium in decreasing proportions (Figs. 9 and 10). 

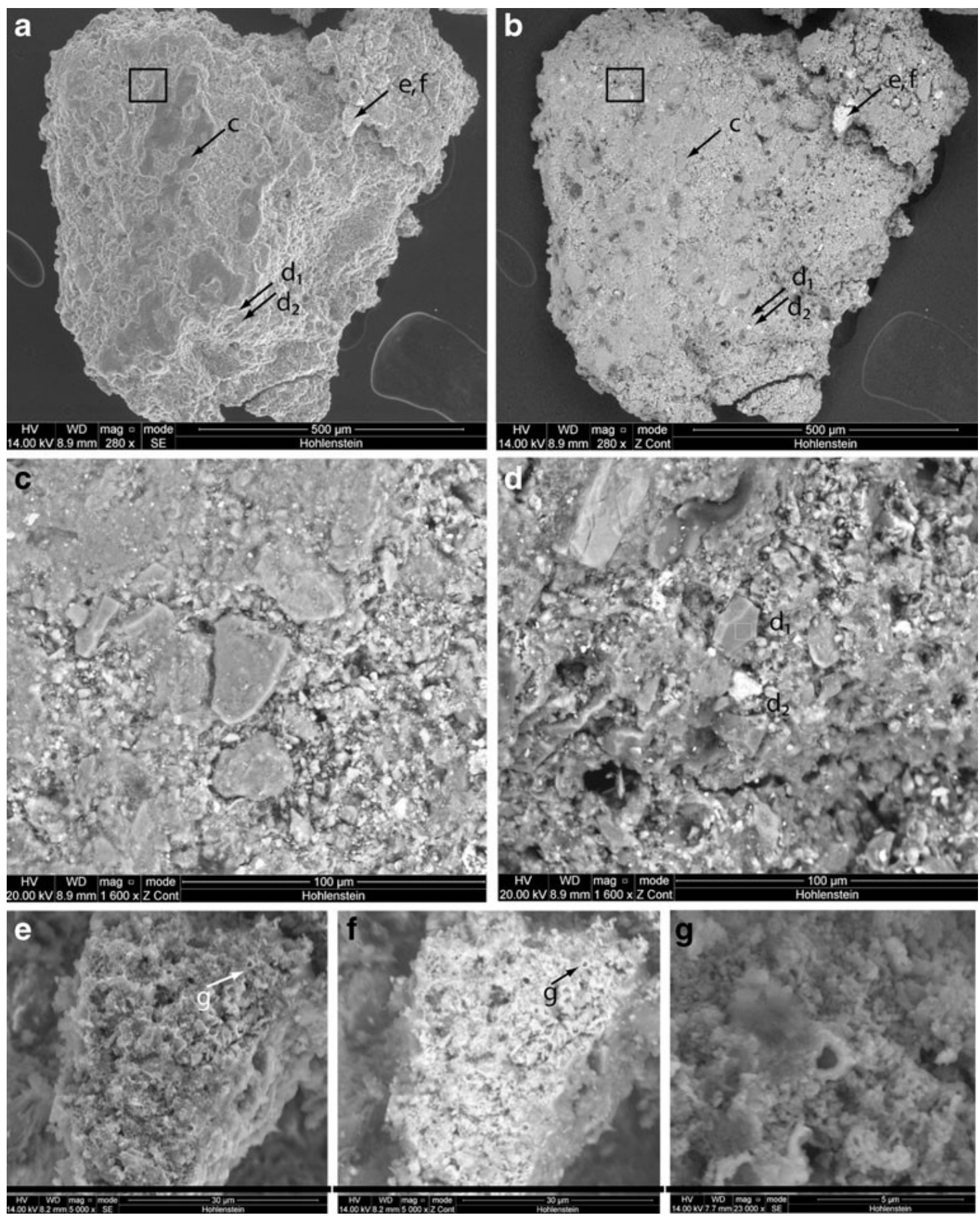

Fig. 9 SEM micrograph in SE mode (a, e, g) and BSE mode (b, c, d, f) of a sample of the pigmented compound attached to the Hohlenstein-Stadel fish tooth no. 6 

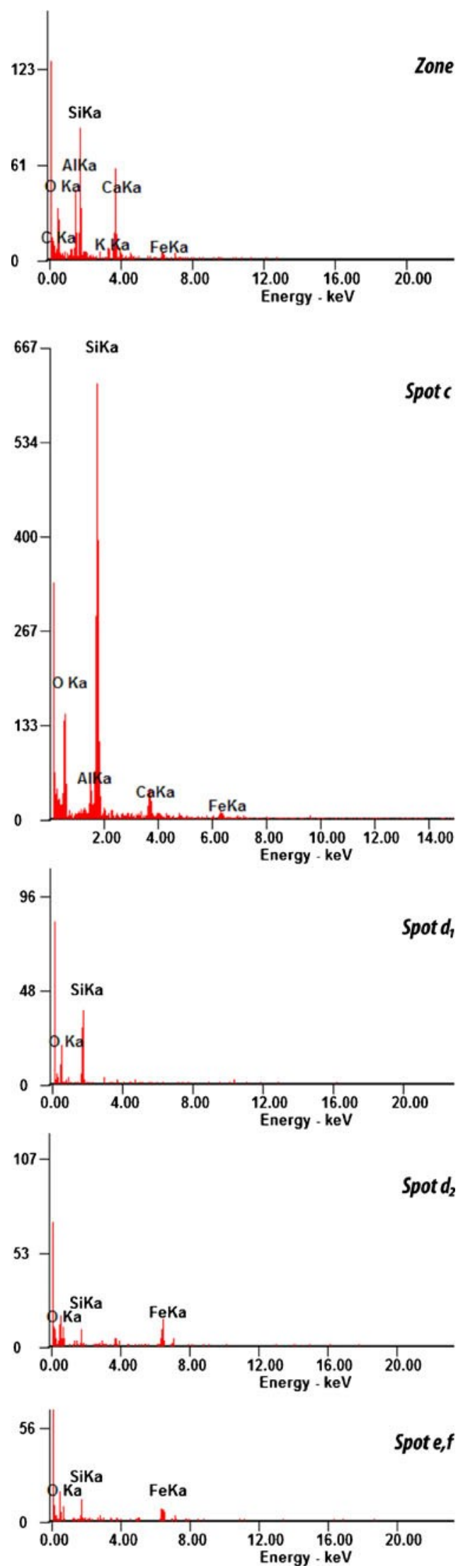

Fig. 10 EDX analyses of selected spots on the residue from Hohlenstein-Stadel tooth no. 6 
Presence of organic material in the residue is evidenced by FTIR spectroscopy analysis, which identifies C-H and $\mathrm{O}-\mathrm{H}$ bands, clearly visible in its domain of absorption $\left(3,200-3,700 \mathrm{~cm}^{-1}\right)$. However, inorganic and organic absorption bands overlap in the first part of the spectrum, preventing a more accurate identification of the organic component (Fig. 11, Table 2).

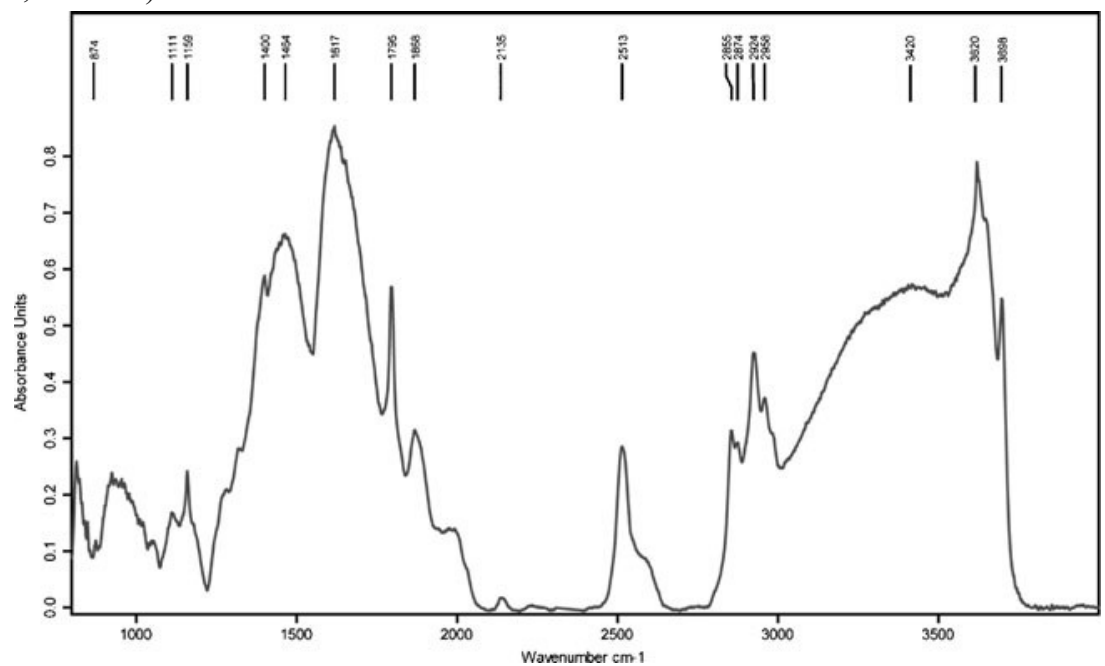

Fig. 11 FTIR analysis of the residue from Hohlenstein-Stadel tooth no. 8

\begin{tabular}{lll}
\hline Compound & Assignment & Wavenumber $\left(\mathrm{cm}^{-1}\right)$ \\
\hline Organic binder & $\mathrm{OH}$ bonds & $1,618, \quad 3,420 \mathrm{w}, 3,620$, \\
& & 3,698 \\
& $\mathrm{CH}_{2}$ and $\mathrm{CH}_{3}$ bonds & $2,855,2,874,2,924,2,958$ \\
& & \\
Calcite & $\mathrm{CO}_{3}$ & $874,1,400,1,795,2,513$
\end{tabular}

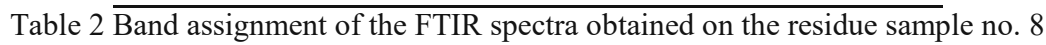

The compound appears to be composed of a clay matrix containing sorted angular fragments of a silica rich mineral, probably quartz (Fig. 10c, d1) associated with smaller iron rich particles (Fig. 10d2, e, f), identified by Raman spectrometry as containing hematite $\left(\mathrm{Fe}_{2} \mathrm{O}_{3}\right)$. High magnification inspection of these particles shows an amorphous structure (Fig. 9e, f) possibly composed of fragmented tests of unicellular organisms (Fig. 9g).

\section{Discussion and conclusion}

Irregular fractures recorded on the bony ankylosis of seven teeth indicate that they were extracted from the pharyngeal bone by flexion. Experiments show that these teeth can be easily extracted from a fresh or boiled pharyngeal fish bone (Cristiani and Borić 2012) suggesting that the teeth were acquired shortly after the capture or consumption of the fish.

The consistent location and appearance of the pigmented compound around the fish teeth bony neck suggests that this material was used as an adhesive to attach the teeth.

Our analysis indicates that the compound is composed of a thin matrix, probably clay, containing particles of charcoal, dolomite, quartz and hematite. The sorted angular appearance of the quartz fragments suggests that quartz was finely ground before being incorporated into the mixture. The alternative hypothesis is that the quartz fragments come from the grindstone used to crush one or more elements composing the residue. The abundance and size homogeneity of the quartz fragments better supports the first hypothesis. The presence of carbon in the fine-grain matrix, the high fluorescence produced by our attempt to analyze it with a $532 \mathrm{~nm}$ Raman spectrometer, the presence of high proportion of $\mathrm{C}-\mathrm{H}$ and $\mathrm{O}-\mathrm{H}$ bands identified by the FTIR analysis, and the adherence of the compound on the teeth, is consistent with the use of an organic binder. Resin, gum, or beeswax are well known 
components of traditional glues (Daher et al. 2010; Wadley 2010). However, the FTIR signal does not identify, in our case, clear chemical fingerprints of the organic binder (d'Errico et al. 2012; Maia et al. 2013).

The addition of ochre and charcoal in the preparation of adhesives used for manufacturing composite tools is attested in the Middle Stone Age of Southern Africa (Lombard 2007; Wadley et al. 2009), the Ibéromaurusian (Ighilahriz 1996) and Caspian of North Africa (Beyries 1983), the Mesolithic of Italy (Cristiani et al. 2009), and the Pre-Pottery Neolithic A (PPNA) (Shaham et al. 2010). The use of adhesives in prehistoric beadwork has been occasionally suggested (Bonnardin 2009; Cristiani and Borić 2012), but never demonstrated. Numerous ethnographic examples suggest that this practice may well have been at work in prehistory (Dubin 1999; Verswijver 1986).

Results presented here lead to the conclusion that carp teeth were suspended using an organic glue to attach a link around their neck. Survey of the literature indicates that carp teeth are found at six other Mesolithic sites (Rigaud 2011, Fig. 12, Table 3). Three of them, Burghöhle Dietfurt (BadenWürttemberg, Germany), Falkensteinhöhle (Bavaria, Germany), and Probstfels (Baden-Württemberg, Germany) located in the Upper Danube region (Newell et al. 1990) and three others, Vlasac (Serbia), Kula (Serbia), and Schela Cladovei (Romania), in the Lower Danube. The three carp teeth used at Burghöhle Dietfurt present a drilled perforation on the lateral aspect of the bony neck (Taute 1990, Fig. 17). Peters (1933 cited in Taute 1990) also mentions a lateral perforation on some of the Falkensteinhöhle carp teeth. At Vlasac, half of the carp teeth were perforated by notching the frontal aspect of the bony neck (Borić 2002; Borić and Miracle; 2004; Cristiani and Borić 2012) while the other half was unmodified and probably attached with organic threads as suggested by purported remains of tendons or skin on the bony neck of some teeth (Cristiani and Borić 2012). Unfortunately, no detailed data are available on the suspension technique of the carp teeth from Probstfels, Schela Cladovei, and Kula. In the Upper Danubian area, the site of Burghöhle Dietfurt yielded carp teeth ornaments associated with perforated red deer canines and fossil gastropods attributed to the Gyraulus sulcatus (Hilgendorf 1866) and Gyraulus trochiformis (Stahl 1824) species (Peters 1934; Rähle 1978, 1981). Carp teeth of Falkensteinhöhle, located in the same region, were associated with perforated red deer and fox canines, a tubular bone bead, shells belonging to the Mediterranean Columbella rustica (Coen 1937) species, as well as perforated fossil gastropods attributed to the Potamides laevissimus (Schloth.) and Pirenella plicata (Bruguiere, 1792) species (Peters 1934; Rähle 1978; Taute 1973-74). At Probstfels, carp teeth were associated with perforated fossil Potamides laevissimus (Peters 1934; Rähle 1978, 1981). In the Lower Danubian area, carp teeth ornaments are associated with Cyclope neritea and C. rustica shells at the cemetery of Vlasac and to C. neritea (Linné 1758) shells at Schela Cladovei.

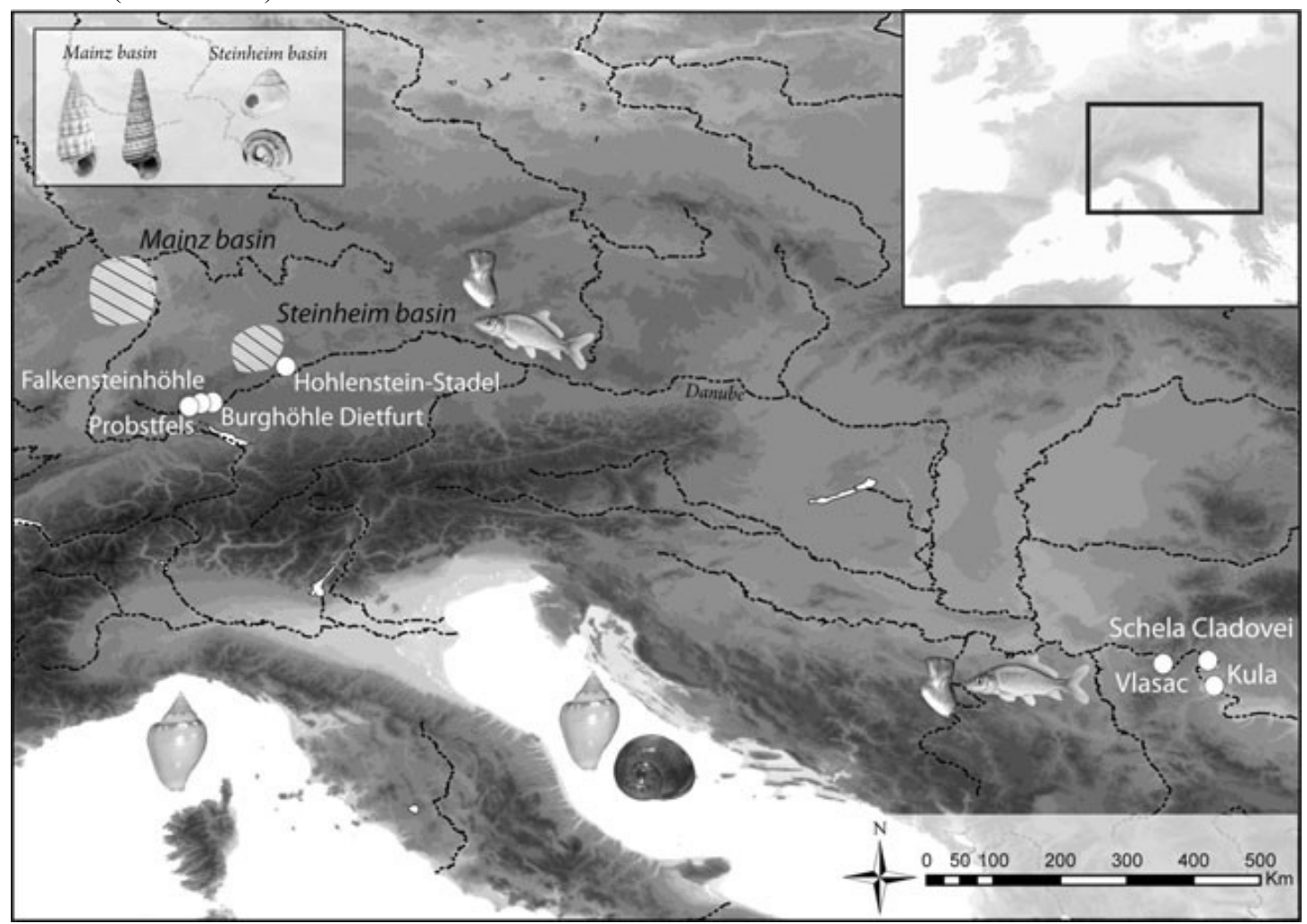

Fig. 12 Synthetic map of raw material used for Mesolithic personal ornamentation along the Danube and their origin 


\begin{tabular}{|c|c|c|c|c|c|}
\hline Site & Location & Layer & Attribution & Bead types & References \\
\hline Probstfels & UD & Camp & $\begin{array}{l}\text { Early/Middle } \\
\text { Mesolithic }\end{array}$ & $\begin{array}{l}\text { Cyprinid teeth } \\
\text { Potamides laevissimus }\end{array}$ & Peters 1934; Rähle 1978, 1981 \\
\hline Falkensteinhöhle & UD & Camp & Middle Mesolithic & $\begin{array}{l}\text { Columbella rustica } \\
\text { Cyprinid teeth } \\
\text { Fox canine } \\
\text { Pirenella plicata } \\
\text { Potamides laevissimus } \\
\text { Red deer canine } \\
\text { Tubular bone bead }\end{array}$ & $\begin{array}{l}\text { Peters 1934; Rähle 1978; Taute 1973- } \\
74\end{array}$ \\
\hline Burghöhle Dietfurt & UD & Camp & Middle Mesolithic & $\begin{array}{l}\text { Gyraulus sulcatus } \\
\text { Gyraulus trochiformis } \\
\text { Red deer canine } \\
\text { Cyprinid teeth }\end{array}$ & Rähle 1978, 1981 \\
\hline Holenstein-Stadel & UD & Burial & Late Mesolithic & Cyprinid teeth & Völzing 1938; Wetzel 1938 \\
\hline Vlasac & LD & Burial & Late Mesolithic & $\begin{array}{l}\text { Columbella rustica } \\
\text { Cyclope neritea } \\
\text { Cyprinid teeth }\end{array}$ & $\begin{array}{l}\text { Borić 2002; Borić and Miracle 2004; } \\
\text { Cristiani and Borić 2012; Srejovic } \\
\text { and Letica } 1978\end{array}$ \\
\hline Schela Cladovei & LD & Burial & Late Mesolithic & $\begin{array}{l}\text { Cyclope neritea } \\
\text { Cyprinid teeth }\end{array}$ & Boroneant 1999 \\
\hline Kula & LD & Burial & Mesolithic & Cyprinid teeth & Radovanovic 1996; Sladic 1986 \\
\hline
\end{tabular}

Table 3 Contextual data on Mesolithic sites yielding Cyprinid pharyngeal teeth ornaments. (UD) Upper Danube, (LD) Lower Danube

Positioning of the carp teeth ornaments on the body also differs between the two areas. Carp teeth ornaments are located on the torso, arms and legs of the deceased in the Iron Gates suggesting they were sewn on a cloth (Cristiani and Borić 2012) while their presence in the sediment surrounding one of the skulls at HohlensteinStadel suggests that they were part of a head-ornament at this site.

In conclusion, the use of cyprinids teeth as personal ornaments in the Mesolithic of the Upper and Lower Danube regions is, in a number of respects, a puzzling cultural phenomenon. It represents a cultural innovation since no previous use of such teeth is attested in prehistory. It appears almost at the same time in two distant regions, which raises the question of the mechanisms (inheritance from an ancestral population, independent invention or diffusion) that may have been responsible for its adoption. It does not reveals, once the objects are analyzed in detail, clear regional trends in the way carp teeth were modified, suspended and worn as one may reasonably expect in the case their use reflected cultural differences between the two regions. In order to choose between these competing hypotheses (inheritance, independent invention, diffusion) we need to analyze other artifact categories from the two regions and put the Mesolithic beads from the Upper and Lower Danube in the context of the Mesolithic bead type variability across Europe.

Acknowledgments We thank Kurt Wehrberger M.A. for giving us access to the collections from the Ulmer Museum and for allowing microsampling of the pigmented compound attached to the carp teeth from Hohlenstein-Stadel. We are also grateful to PD Dr. J. Orschiedt and Pr. W. Rähle for their help in finding publications on the Große Ofnet and Hohlenstein-Stadel head burials, to M. Véran and J. Gaudant for sharing paleontological information on cyprinids and to I. Svahn from the Bordeaux Imaging Center for performing the SEM and EDX analyses. We thank Renata Garcia Moreno, Pierre Guyomarc'h, Carlotta Tavormina and Brad Gravina for critical reading of the manuscript. This research was funded by the French Ministry of Higher Education and Research and the European Research Council (FP7/2007/2013/ERC Grant TRACSYMBOLS no 249587). The final stage of this study was conducted during a post-doctoral grant attributed to one of us (SR) by the Fyssen Foundation. 


\section{References}

Albrethsen SE, Brinch-Petersen E (1976) Excavation of a Mesolithic cemetery at Vedbaeck, Denmark. Acta Archaeol-Den 47:6-28

Barel CD, Witte F, van Oijen JP (1976) The shape of the skeletal elements in the head of a generalized haplochromis species: H. elegans trewavas 1933 (Pisces, Cichlidae). Neth J Zool 26:163-235

Beyries S (1983) Fonction et mode d'utilisation d'une série de lames ocrées capsiennes. In: Cauvin MC (ed) Traces d'Utilisation Sur Les Outils Néolithiques Du Proche Orient. Maison de L'Orient, Lyon, pp 135-142

Bolus M, Conard NJ, Kandel AW (1999). Grabungen vor dem Hohlenstein im Lonetal, Gemeinden Bissingen und Asselfingen, AlbDonauKreis. Archäologische Ausgrabungen in Baden-Württemberg 1998. Konrad Theiss Verlag GmbH, Stuttgart, pp 40-47

Bonnardin S (2009) La parure funéraire au Néolithique ancien dans les Bassins parisien et rhénan-Rubané, Hinkelstein et VilleneuveSaint-Germain. Mémoire de la Société Préhistorique Française, Paris

Borić D (2002) Apotropaism and the temporality of colours: colourful Mesolithic-Neolithic seasons. In: Jones A, Mac Gregor G (eds) Colouring the past: the significance of colour in archaeological research. Berg, Oxford, pp 23-43

Borić D, Miracle PT (2004) Mesolithic and Neolithic (dis)continuities in the Danube Gorges: new AMS dates from Padina and Hajducka Vodenica (Serbia). Oxf J Archaeol 23:341-371

Boroneant V (1999) The Mesolithic Habitation Complexes in the Balkans and Danube Basin. Living Past 1:1-15

Chebotareva YV, Izyumov YG, Krylov VV (2009) The Effect of an alternating electromagnetic field upon early development in roach (Rutilus rutilus: Cyprinidae, Cypriniformes). J Ichthyol 49:409-415

Cristiani E, Borić D (2012) 8500-year-old Late Mesolithic garment embroidery from Vlasac (Serbia): Technological, use-wear and residue analyses. J Archaeol Sci 39:3450-3469

Cristiani E, Pedrotti A, Gialanella S (2009) Tradition and innovation between the Mesolithic and Early Neolithic in the Adige Valley (north-east Italy). New data from a functional and residues analyses of trapezes from Gaban rockshelter 1. Documenta Praehistorica XXXVI: 191-205

d'Errico F, Rigaud S (2011) Crache perforée dans le Gravettien du sire (Mirefleurs, Puy-de-Dôme). PALEO 22:301-310

d'Errico F, Vanhaeren M (2002) Criteria for identifying red deer (Cervus elaphus) age and sex from their canines. Application to the study of Upper Palaeolithic and Mesolithic Ornaments. J Archaeol Sci 29:211-239

d'Errico F, Backwell L, Villa P, Degano I, Lucejko JJ, Bamford MK, Higham TFG, Colombini MP, Beaumont PB (2012) Early

evidence of San material culture represented by organic artifacts from Border Cave, South Africa. PNAS 109:13214-13219

Daher C, Paris C, Le Hô AS, Bellot-Gurlet L, Échard JP (2010) A joint use of Raman and infrared spectroscopies for the identification of natural organic media used in ancient varnishes. J Raman Spectrosc 41:1494-1499

Dinnis R, Pawlik A, Gaillard C (2009) Bladelet cores as weapon tips? Hafting residue identification and micro-wear analysis of three carinated burins from the late Aurignacian of Les Vachons, France. J Archaeol Sci 36:1922-1934

Downs RT (2006) The RRUFF Project: an integrated study of the chemistry, crystallography, Raman and infrared spectroscopy of minerals. Program and Abstracts of the 19th General Meeting of the International Mineralogical Association in Kobe, Japan

Dubin LS (1999) North American Indian jewelry and adornment. From prehistory to the present. Abrams, New York

Eriksen BV (2002) Fossil Mollusks and Exotic Raw Materials in Late Glacial and Early Find Contexts: A Complement to Lithic Studies. In: Fisher LE, Eriksen BV (eds) Lithic raw material economy in late glacial and early postglacial Western Europe. Bar International Series, Oxford, pp 27-52

Fraser GJ, Hulsey CD, Bloomquist RF, Uyesugi K, Manley NR, Streelman JT (2009) An ancient gene network is co-opted for teeth on old and new jaws. PLoS Biol 7:e1000031

Freyhof J (2002) Freshwater fish diversity in Germany, threats and species extinction. In: Collares-Pereira MJ, Coelho MM (eds) Conservation of freshwater fishes: options for the future. Fishing News, Oxford, pp 3-22

Gieseler W (1951) Die suddeutschen Kopfbestattungen (Ofnet, Kaufertsberg, Hohlenstein) und ihre zeitliche Ein-reihung. Naturw Mschr Aus der Heimat 59:291-298

Haas S (1991) Urgeschichte in Oberschwaben und der mittleren Schwäbischen Alb. Zum Stand neuerer Untersuchungen der SteinzeitArchäologie. Archäologische Informationen aus BadenWürttemberg 37-38

Hardy BL, Moncel MH (2011) Neanderthal use of fish, mammals, birds, starchy plants and wood 125-250,000 years ago. PLoS ONE 6: e23768

Hardy BL, Bolus M, Conard NJ (2008) Hammer or crescent wrench? Stone-tool form and function in the Aurignacian of southwest Germany. J Hum Evol 54:648-662

Hensel K (1979) Rutilus (Pararutilus) frisii meidingeru in the Czechoslovak stretch of the Danube River. Vestnak Czechoslovenske Spolecnosti Zoologicke 18:250-252

Ighilahriz F (1996) L'ocre dans l'industrie lithique de l'Ibéromaurusien d'Afalou Bou-Rhummel (Algérie). Anthropologie 100:77-87

Kind CJ, Beutelspacher T (2009) Neue Ausgrabungen am HohlensteinStadel im Lonetal, Gde. Asselfingen, Alb-Donau-Kreis. Archäeologische Ausgrabungen in Baden-Württemberg 2008:27-31

Komšo D, Vukosavljević N (2011) Connecting coast and inland: perforated marine and freshwater snail shells in the Croatian Mesolithic. Quat Int 244:117-125

Kottelat M, Freyhof J (2007) Handbook of European freshwater fishes. Cornol, Switzerland, Kottelat

Larsson L (2006) A tooth for a tooth. Tooth ornaments from the graves at the cemeteries of Zvejnieki. In: Larsson L, Zagorska I (eds) Back to the Origin: New Research in the Mesolithic-neolithic Zvejnieki Cemetery \& Environment, Northern Latvia. Wallin \& Dalholm, Lund, pp 253-287 
Lombard M (2007) The gripping nature of ochre: the association of ochre with Howiesons Poort adhesives and Later Stone Age mastics from South Africa. J Hum Evol 53:406-419

Lombard M, Pargeter J (2008) Hunting with Howiesons Poort segments: pilot experimental study and the functional interpretation of archaeological tools. J Archaeol Sci 35:2523-2531

Maia M, Barros AI, Nunes MF (2013) A novel, direct, reagent-free method for the detection of beeswax adulteration by singlereflection attenuated total reflectance mid-infrared spectroscopy. Talenta 107:74-80

Mercader J, Bennett T, Raja M (2008) Middle Stone Age starch acquisition in the Niassa Rift, Mozambique. Quat Res 70:283-300

Mikschi E, Wolfram-Wias A (1999) Fische und Neunaugen, Eine Rote Liste der in Niederösterreich gefährdeten Arten. Rote Listen ausgewählter Tiergruppen Niederösterreichs; Hrsg. Amt der NÖ Landesregierung, Abt. Naturschutz und Abt. Agrarrecht, St. Pölten

Newell RR, Kielman D, Constandse-Westermann TS, van der Sanden WAB, van Gijn A (1990) An inquiry into the ethnic resolution of Mesolithic regional groups: the study of their decorative ornaments in time and space. Brill, Leiden

O'Shea J, Zvelebil M (1984) Oleneostrovski mogilnik: reconstructing the social and economic organization of prehistoric foragers in Northern Russia. J Anthropol Archeol 3:1-40

Orschiedt J (1998) Ergebnisse einer neuen Untersuchung der spätmesolithischen Kopfbestattungen aus Süddeutschland. In: Conard NJ, Kind JC (eds) Aktuelle Forschungen Zum Mesolithikum, pp147-160

Orschiedt J (1999) Manipulationen an menschlichen Skelettresten. Taphonomishe Prozesse, Sekundärbestattungen oder Kannibalismus? Urgeschichtliche Materialhefte 13: Mo, Vince

Peters E (1934) Die Falkensteinhoehle bei Tiergarten. Fundberichte aus Hohenzollern 3:2-12

Radovanovic I (1996) The Iron Gates mesolithic. International Monographs in Prehistory, Ann Arbor

Rähle W (1978) Schmuckschnecken aus mesolithischen Kulturschichten Süddeutschlands und ihre Herkunft (Probstfeld, Falkensteinhöhle, Burghöhle Dietfurt, Zigeunerfels, Große Ofnet). In: Taute W (ed) Das Mesolithikum in Süddeutschland Teil 2. Tübingen Monographien zur Urgeschichte, Tübingen, pp 163-268

Rähle W (1981) Schmuckschnecken aus Jungpaläolithischen Fundschichten vom Hohlen Fels bei Schelklingen (Alb-DonauKreis). Archaol Korresponden 11:179-180

Rauther M (1935) Fischreste aus der mesolithischen Kulturschicht der Falkensteinhöhle an der oberen Donau. In: Lindner E (ed), Jahreshefte Des Vereins Für Vaterländische Naturkunde in Württemberg. Schwendsche Buchdruckerei, Schwäbisch Hall, pp $121-124$

Rigaud S (2011) La parure: traceur de la géographie culturelle et des dynamiques de peuplement au passage Mésolithique-Néolithique en Europe. University of Bordeaux. Unpublished PhD dissertation. Available at http://tel.archives-ouvertes.fr/tel-00668694

Rigaud S, d'Errico F, Vanhaeren M (2010) Los objetos de adorno personal asociados al esqueleto mesolítico Braña-2. In: Vidal Encinas JM, Encina Prada M (eds) Los Hombres Mesolíticos De La Cueva De La Braña-Arintero (Valdeugueros, León). Museo de Leon, Leon, pp 62-81

Roksandic M (2006) Violence in the Mesolithic.Documenta Praehistorica XXXIII: 165-182

Rots V, Van Peer P, Vermeersch PM (2011) Aspects of tool production, use, and hafting in Palaeolithic assemblages from Northeast Africa. J Hum Evol 60:637-664

Schmidt RR (1912) Die diluviale Vorzeit Deutschlands. Unter Mitwirkung von E. Koken und A. Schliz. E Schweizerbartsche Verlagsbuchhandlung Nägele und Dr. Sproesser, Stuttgart

Shaham D, Grosman L, Goren-Inbar N (2010) The red-stained flint crescent from Gesher: new insights into PPNA hafting technology. J Archaeol Sci 37:2010-2016

Sladic M (1986) Kula pre Mihajlovac - un site préhistorique. Đerdapske sveske - Cahiers des Portes de fer III: 271-285

Srejovic D, Letica Z (1978) Vlasac vol. I, Serbian Academy of Sciences and Arts, Belgrade

Taute W (1973-1974) Neue forschungen zur Chronologie vom Spätpaläolithikum und Mesolithikum in Süddeutschland. Archäologische Informationen 2-3: 59-66

Taute W (1990) Die Grabungen 1988 und 1989 in der Burghöhle Dietfurt an der oberen Donau, Gemeinde Inzigkofen-Vilsingen, Kreis Sigmaringen, in Archäologische Ausgrabungen in BadenWürttemberg 1989. Konrad Theiss Verlag GmbH \& Co., Stuttgart, pp $38-44$

Thorpe IJN (2003) Anthropology, archaeology and the origin of warfare. World Archaeol 35:145-165

Tuinstra F, Koenig JL (1970) Raman spectrum of graphite. J Chem Phys 53:1126-1130

Vanhaeren M, d' Errico F (2003) The Body Ornaments Associated with the Burial. In: Zilhao J, Trinkaus E (eds) Portrait of the artist as a child. The Gravettian human skeleton from the Abrigo Do Lagar Velho and its archaeological context. Instituto Portugues de Archeologia, Lisbonne, pp 154-186

Vanhaeren M, d'Errico F (2005) Grave goods from the Saint-Germain-laRivière burial: evidence for social inequality in the Upper Palaeolithic. J Anthropol Archaeol 24:117-134

Vanhaeren M, d'Errico F (2006) Aurignacian ethno-linguistic geography of Europe revealed by personal ornaments. J Archaeol Sci 33:1-24

Verswijver G (1986) Analyse comparative des parures Nahua: similitudes et différences. Bull Annu Musée d'Ethnographie de la Ville de Genève 29:25-67

Völzing O (1938) Die Grabungen 1937 am Hohlestein im Lonetal, Fundberichte aus Schwaben. Neue Folge IX: 1-7

Wadley L (2010) Compound-adhesive manufacture as a behavioral proxy for complex cognition in the Middle Stone Age. Curr Anthropol 51: 111-119

Wadley L, Hodgskiss T, Grant M (2009) Implications for complex cognition from the hafting of tools with compound adhesives in the Middle Stone Age. S Afr Proc Natl Acad Sci. doi:10.1073/pnas. 0900957106 
Wetzel R (1938) Die Kopfbestattung und die Knochentrümmerstätte des Hohlensteins im Rahmen der Urgeschichte des Lonetals. Verhandlungen der Deutschen Gesellschaft für Rassenforschung Band IX: 13-212

White R (2008) Systems of personal ornamentation in the early Upper Palaeolithic: methodological challenges and new observations. In: Mellars P, C Stringer C (eds) Rethinking the Human Revolution: New Behavioural \& Biological Perspectives on the Origins and Dispersal of Modern Humans, McDonald Institute for Archaeological Research, pp 1-30

Zheltenkova MV (1949) Food and growth in genus. Rutilus Zool Zh 29: 257-267 